4. Трофимова Н. Н., Зак П. П., Островский М. А. функциональная роль каротиноидов желтого пятна сетчатки глаза // Сенсорные системы. - 2008. - Т. 17(3). C. $198-208$.

5. Шальк Вольфган Лютеин и зеаксантин: два основных компонента для здоровья глаз // Офтальмол. журнал. - 2009. - № 5. - С.76-79.

6. Bellmann C., Rubin G. S., Kabanarou S. A., et al. Fundus autofluorescence imaging compared with different confo- cal scanning laser ophthalmoscopes // Br J Ophthalmol. 2003; 87 (11). - P.1381-6.

7. Bone R. A., Landrum J. T., Dixon Z., Chen Y. Lutein and Zeaxanthin in the Eyes, Serum and Diet of Human Subjects // Exp. Eye Res. - 2010. - № 3. - P. 239245.

Поступила 08.06.2011

Рецензент д-р мед. наук Н. Н. Бушуева

\title{
OCUVITE-LUTEIN FORTE IN THE TREATMENT OF MYOPIC MACULOPATHY WITH A HIGH DEGREE OF MYOPIA
}

G. D. Zhaboiedov, O. V. Petrenko, D. G. Zhaboiedov

Kiev, Ukraine

We have studied the influence of Ocuvite-lutein forte on the condition of macular area in patients with myopic macuopathy at myopia of high degree. Positive effect of balanced vitamin-mineral complex Ocuvite-lutein forte was revealed on functional and morphological state of retina in patients with myopic maculopathy, which had been confirmed by subjective and objective data.

УдК 617.753.2:617.7-76-053.2-008.9

\section{О СТАБИЛИЗАЦИИ ПРИОБРЕТЁННОЙ МИОПИИ У ДЕТЕЙ С ПОМОЩЬЮ КОНТАКТНЫХ ЛИНЗ В СВЕТЕ МЕТАБОЛИЧЕСКОЙ ТЕОРИИ МИОПИИ}

\author{
М. Г. Гусева, врач-офтальмолог ЛДЦ «СПб. Водоканал»,
}

О. В. Светлова, доц. д.м.н. доцент каф. «Офтальмологии» СПб. МАПО,

И. Н. Кошиц, ген. дир. ЗАО «Питерком-Сети / МС»

Лечебно-диагностический центр ГУП ОАО «СПб. Водоканал», Санкт-Петербургская Медицинская Академия последипломного образования, ЗАО «Питерком-Сети / МС Консультационная группа», Россия, Санкт-Петербург

Встановлено, що при обгрунтованому використанні повної корекції прогресування набутої міопії у здорових дітей 5-14 років значно зменшувалось. В результаті використання м'яких контактних лінз (МКЛ) відновлювався запас акомодації відповідно віковій нормі, співвідношення акомодаційної конвергенції до акомодації також відповідало межам норми. Трофічні зміни на очному дні, обумовлені стадіями короткозорості, при застосуванні МКЛ були виражені в меншому ступені, ніж при корекиіі окулярами. Ще більш ефективним засобом корекції були ортокератологічні лінзи (ОКЛ).

Одержані клінічні результати автори пов'язують з метаболічною теорією розвитку міопії, викладеною у статті.

Ключевые слова: приобретенная миопия, детский возраст, мягкие контактные линзы, аккомодация, метаболизм.

Ключові слова: набута міопія, дитячий вік, м'які контактні линзі, акомодація, метаболізм.

Актуальность и теории миопии. Миопия не только самый распространенный вид нарушения клинической рефракции, но и состояние, которое в значительной степени ограничивает жизнедеятельность человека и качество его жизни. В США, как и во многих развитых странах, распространенность близорукости среди взрослого населения сегодня составляет не менее $45 \%$, а в Японии, Гонкон- ге и Китае миопы составляют от $70 \%$ и выше [46]. Наоборот, в слаборазвитых странах, где люди мало работают на близком расстоянии, близорукость не превышает $10 \%$, поскольку такой образ жизни не требует продолжительной напряжённой работы вблизи. 
Эти данные говорят не только о значительном негативном воздействии современной «дисплейной» цивилизации на зрительную систему человека, но и показывают явную несостоятельность существующих в мире теорий миопии, поскольку переломить эпидемиологический характер вышеуказанной тенденции в масштабах человечества пока не удалось. Особенно опасна «тотальная дисплеизация» для глаз в детском возрасте.

С учетом географического фактора увеличение показателей близорукости отмечается с юга на север [2], когда (как нам теперь стало понятно) общее падение освещённости провоцирует более напряжённую работу глаза, следствием чего является естественная начальная миопизация зрительной системы человека. В этой связи стоит отметить возможную опасность массового перехода на энергосберегающие лампы белого цвета, спектр которых (при формально достаточной освещённости по нормам) отличается от естественного спектра солнечного света или обычных ламп накаливания с вольфрамовой нитью, что, по-видимому, может снижать контрастную чувствительность и провоцирует более напряжённую работу зрительного анализатора. Поэтому запланированный законодательный переход многих европейских стран на энергосберегающие лампы «дневного» света требует ускоренного проведения сравнительных эргономических исследований по физиологической эффективности таких ламп при работе глаза вдаль и вблизи, как часть регламента зрительной работы.

Близорукость может способствовать развитию серьезной офтальмопатологии, такой как дегенерация сетчатки, отслойка сетчатки, глаукома, амблиопия и косоглазие. Наличие миопии в 1,0 Д ограничивает пространство наилучшего видения одним метром, поэтому понятна важность назначения рациональной оптической коррекции миопии особенно в детском и подростковом возрасте. В СССР в основном применялась полная коррекция миопии [6], однако позже стало преобладать мнение о благоприятном воздействии неполной коррекции миопии на степень её прогрессирования [8]. Такая позиция была основана на предположении, что недокоррекция уменьшает зрительную нагрузку на аккомодацию и замедляет рост близорукости. Зарубежные врачи и оптометристы, наоборот, считают, что недокоррекция может вести к прогрессированию миопии из-за постоянного присутствия дефокуса, ослабления аккомодации, ведущих к нарушению трофики и в результате - к удлинению глазного яблока [39]. Поэтому сегодня российская офтальмологическая школа имеет ряд отличий в решении этой проблемы по сравнению со стратегией многих зарубежных коллег.

В настоящее время в России уже около половины школьников выпускаются по окончании школы с близорукостью (и эти данные коррелируют с мировой тенденцией) [20]. Однако, в РФ по-прежнему преобладает мнение о благоприятном воздействии неполной коррекции близорукости на скорость её прогрессирования, а первичное назначение очков часто необоснованно затягивается и определяется наличием близорукости в 3,0 Д.

Патогенез и профилактика, теории приобретённой миопии. Сегодня большинству офтальмологов стало понятно, что необходимо так изменить зрительную нагрузку, чтобы ПМ не прогрессировала, но как грамотно подобрать эти тормозящие изменения, пока было не ясно. Одновременно следует учитывать, что на развитие ПМ влияет несовершенство профилактики и лечения в период формирования зрительной системы в детском возрасте, несвоевременное обращение пациентов, отсутствие или несовершенство системы раннего выявления офтальмопатологии у детей, а также, зачастую, отсутствие материально-технических условий для организации лечения.

«Полярность мнений» в представлениях о патогенезе приобретённой миопии и адекватности профессиональных действий у оптометристов или у врачей-офтальмологов, подбирающих очки или линзы, достигла критического уровня. В результате ПМ успешно и ускоренно продолжает прогрессировать во всех странах, а эффективные средства борьбы с этой так называемой «зрительной эпидемией» пока в мире не найдены. И связано это с тем, что причины возникновения и прогрессирования ПМ весьма сложны. Тут участвует множество различных внутренних и внешних факторов, связанных со зрительными нагрузками, которые резко увеличивают вероятность возникновения развития ПМ [1, $3,18,23,32,35]$. Возникшую ситуацию необходимо срочно и в корне менять.

Все известные за последние два века теории миопии не смогли обнаружить ключевое исполнительное звено в механизме удлинения ПЗО глаза. Однако уровень накопленных знаний оказался настолько значительным, что можно было надеяться на «переход количества в качество». Ближе всех к решению вопроса о ключевом исполнительном механизме удлинения оси глаза, по нашему мнению, подошли В. И. Добровольский (1898) [9] и Э. С. Аветисов (1986) [2].

В. И. Добровольский считал, что развитие спазма аккомодации при эмметропии или гиперметропии способствует появлению видимой миопии - псевдомиопии. По его мнению, более $80 \%$ слабой миопии (до 0,5 Д) вызваны спазмом аккомодации. В 60 \% случаев спазм аккомодации имеется при миопии любых степеней [9].

Э. С. Аветисов считал, что главная роль в возникновении и прогрессировании близорукости принадлежит ослаблению аккомодации, чему спо- 
собствуют неблагоприятные условия окружающей среды, интенсивная работа на близком расстоянии, сопутствующие общие заболевания, нерациональная коррекция зрения. При ослаблении аккомодации усиленная зрительная работа на близком расстоянии становится для глаз непосильной нагрузкой. Организм вынужден так изменить оптическую систему глаза, чтобы приспособить ее к работе на близком расстоянии без напряжения аккомодации [2]. Это достигается за счет удлинения переднезадней оси глаза в период его роста и формирования рефракции. Причём ось может удлиняться даже у взрослого человека, чтобы приспособить глаз к работе на близком расстоянии.

Согласно гипотезе Э. С. Аветисова [2], в механизме происхождения миопии следует выделить два основных звена:

- несоответствие между возможностями ослабленного аккомодационного аппарата глаза и зрительной нагрузкой;

- ослабление прочностных свойств склеры и её динамическое усталостное растяжение под влиянием внутриглазного давления.

В происхождении близорукости, по общему мнению всех исследователей, существенное значение имеет генетический фактор, причем одна форма миопии наследуется по аутосомно-доминантному типу, а другая - по аутосомно-рецессивному типу. При этом большинство согласно с тем, что генетический фактор является важнейшей причиной ослабления склеры при наследственной миопии. Причём многие клиницисты считают, что врожденная близорукость связана с растяжением глаза, а приобретенная - со спазмом аккомодации. А. И. Дашевский считал, что псевдомиопия предшествует удлинению глаза. Он приводил пример, что у школьников без лечения ложная миопия в течение года переходила в истинную. Поэтому необходимо «сначала лечить, устраняя спазм аккомодации, и только затем окончательно корригировать» $[7,8]$.

Эти исследования стали предпосылкой для советской офтальмологической школы, длительное время считавшей, что предупредить спазм аккомодации, уменьшить нагрузку на аккомодацию можно с помощью неполной коррекции близорукости. Западные коллеги и уже некоторые отечественные исследователи-офтальмологи считают, что спазм аккомодации - это временное состояние и встречается не у каждого миопа, а недокоррекция близорукости и астигматизма, наоборот, являются стимулом для удлинения глазного яблока, прогрессирования близорукости [40-42, 44].

Диагностические исследования советской офтальмологической школы были направлены на выявление спазмов аккомодации, а деятельность офтальмологов зарубежной школы направлена на выявление скрытых нарушений мышечного равновесия, нарушений вергенции и фории [43]. Лечение пациентов с близорукостью советскими офтальмологами сводилось к применению медикаментозных, ортоптических и хирургических методов. Зарубежные офтальмологи сводят лечение к восстановлению физиологического соотношения АK/A, назначению адекватной оптической коррекции, ведущей к достижению «зоны комфорта». Регулярное применение циклоплегии в практике российских офтальмологов критикуется западными коллегами, так как действие этих препаратов ослабляет цилиарную мышцу и тем самым может явиться причиной прогрессирования близорукости. Имеются зарубежные исследования, показывающие негативный эффект постоянной недокоррекции [39].

Определённый прогресс в разработке теории патогенеза ПМ недавно достигнут российскими исследователями на стыке физиологии, биомеханики и офтальмологии [11, 13-17, 25-29]. Согласно этой метаболической теории приобретённой миопии, прогрессирование ПМ связано, по мнению авторов, в первую очередь с нарушением нормального метаболизма тканей задней части склеры по физиологическим или механическим причинам, что приводит к ответному (и вначале полезному) росту длины передне-задней оси глаза [26].

Вполне вероятно, что прогрессирование миопии у человека связано с работой более общего физиологического механизма, доставшегося нам от животных: это биомеханизм подбора длины ПЗО под наиболее продолжительную зрительную нагрузку для оптимизации энергопотребления глаза. Поэтому интенсивная моно- или бинокулярная работа вблизи зачастую приводит к функциональной недостаточности увеосклерального оттока водянистой влаги и к прогрессированию ПМ (см. статью И. Н. Кошица и О. В. Светловой в этом номере журнала). Рассмотренные представления сформулированы авторами в виде аналитических гипотез о биомеханизмах прогрессирования ПМ по нагрузочному или разгрузочному типам, которые, без сомнения, требуют клинической апробации, однако чётко объясняют все известные клинические факты, включая полученные в данном и других наших исследованиях [5, 6].

Подводя итог этому разделу, следует отметить, что реализуемый «рабочий» объём аккомодации в конкретном глазу относительно физиологически заложенного полного функционального диапазона работы цилиарной мышцы зависит от степени близорукости и от её адекватной коррекции. Фактически именно адекватная коррекция обеспечивает реализацию всегда имеющегося в глазу физиологического объёма аккомодации, когда оптимальное корригирование оптической системы глаза будет выводить предустановку аккомодации на расстоя- 
ние 1,2-1,5 метра (в условиях не предъявления зрительного стимула) как в нормальном эмметропическом глазу [37]. Поэтому рациональная адекватная оптическая коррекция должна создавать такие физиологические условия работы аккомодационной системы глаза, которые обеспечивают использование всего заложенного в глазу функционального объёма аккомодации.

В вопросе полной или частичной коррекции астигматизма пока нет окончательной ясности, потому что нет общепринятого понимания того, зачем он нужен человеку [22]. И здесь явно необходимы углублённые фундаментальные и клинические исследования работы механизма аккомодации в более сильном меридиане. Возможность неравномерной аккомодации в разных меридианах, включая и вертикальный, была описана ещё В. И. Добровольским (1898) [9], однако почти век офтальмологи не смогли подтвердить эту гипотезу в клиническом эксперименте. Клиническое подтверждение наличия этого аккомодационного механизма неравномерной аккомодации у детей было получено в 2004 г. впервые в мире В. И. Сердюченко и И. А. Вязовским по оригинальной методике [30].

Наша точка зрения на «полезность» естественного физиологического астигматизма такова. Сформированная к 4-5 годам рефракционная система глаза ребёнка имеет прямой астигматизм в 1,0-1,2 D [12, 24, 33], который сохраняется на протяжении всей жизни до 60 лет (и часто после 60-ти) практически у всех землян [24]. Этот прямой астигматизм необходим человеку для функционирования одного из важнейших (и относительно быстрых!) механизмов дополнительной аккомодации [25,26]: неравномерной аккомодации в вертикальном меридиане, которая позволяет быстрее (и более эргономично) опознать опасность и, следовательно, увеличить выживаемость человека как вида. Отметим для сравнения, что у черепахи неравномерную аккомодацию в вертикальном меридиане, кроме цилиарной мышцы, обеспечивает отдельная дополнительная мышца ленточного типа, то есть это достаточно древний механизм ускоренной дополнительной аккомодации, которому более 150 миллионов лет [36]. И «бороться» с ним, полностью нивелируя прямой астигматизм, по меньшей мере некорректно: природа оптимизирует биологические системы.

Сказанное убеждает нас в том, что полное нивелирование прямого астигматизма у человека фактически убивает естественный дополнительный механизм неравномерной аккомодации в вертикальном меридиане, необходимый «по жизни» для всех людей Земли. И только в инволюционном периоде жизни (60-75 лет) прямой астигматизм переходит в обратный или смешанный из-за деформации опорного (для роговицы!) корнеосклерального кольца, вызванного нерав- номерными изменениями толщины склеры [10] из-за естественного повышения офтальмотонуса с возрастом. Максимальное физическое напряжение испытывает цилиарная мышца при коррекции смешанного астигматизма [34], и поэтому его, повидимому, целесообразно нивелировать до физиологического уровня прямого астигматизма. А вот приобретённый обратный астигматизм в пожилом возрасте возможно, целесообразно нивелировать до значений прямого астигматизма, но уже в горизонтальном меридиане для сохранения неравномерной аккомодации. Все приведённые последние положения, конечно, нуждаются в обоснованной клинической проверке.

Как показала работа [23], коррекция контактными торическими линзами прямого астигматизма предпочтительнее в сравнении с очковой коррекцией. Это связано с тем, что очковая коррекция астигматизма чаще неполная, поскольку назначается по принципу переносимости. Коррекция астигматизма контактными линзами возможна полная (до уровня естественного прямого астигматизма в 1,0-1,2 D), при этом восстанавливается относительная сферичность оптической системы глаза. В наших исследованиях мы применяли коррекцию прямого астигматизма до уровня физиологического в 1,0-1,2 D.

C учётом сказанного, можно предположить, что ранняя адекватная коррекция близорукости и астигматизма контактными линзами и ортокератологическими линзами приведёт к замедлению прогрессирования ПМ, поскольку будет нормализовано состояние аккомодации и конвергенции, восстановлена трофика, устранено явление дефокуса. То есть будут устранены главные и сопутствующие причины, приводящие к удлинению глазного яблока и его неравномерному растяжению.

Цель работы. Провести сравнительное исследование эффективности длительного ношения мягких контактнах линз, ортокератологических линз и неполной очковой коррекции миопии в плане оценки характера её прогрессирования.

МАТЕРИАЛ И МЕТОДЫ. Наблюдения за детьми и подростками с миопией различных степеней и миопическим астигматизмом (миопией средней степени по сфероэквиваленту) велось на протяжении 5 лет в трёх группах: первая возрастная группа от 5 до 14 лет численностью 180 человек, носящих мягкие контактные линзы, вторая в возрасте от 7 до 14 лет численностью 45 человек, использующих ортокератологические линзы. Третья контрольная группа состояла из 90 пациентов того же возраста, носящих очки (с неполной коррекцией, бифокальные, прогрессивные). Смещение фокуса за сетчатку за счёт слабой гиперкоррекции в МКЛ контролировалось с помощью дуохромного теста.

В качестве методов исследования использовались следующие:

1. Авторефкератометрия - основной метод объективного исследования рефракции пациента.

2. Циклоплегия по показаниям с помощью Sol. Cyclomedi $1 \%$, 3-х кратно в течение 45 минут. 
3. Субъективное определение рефракции с помощью пробного набора очковых линз.

4. Определение силы сферы методом затуманивания с помощью линзы силой $+1,5$ Д.

5. Уточнение силы цилиндра и направления его оси с помощью кросс-цилиндров Джексона на основании результатов объективного исследования.

6. Тесты для проверки сферической коррекции - дуохромный тест, тест с диафрагмой.

7. Проверка бинокулярного зрения: разобщение с помощью цветных, а также поляризационных фильтров.

8. Выявление фории и ее оценка с помощью цилиндра Maddox и призматического компенсатора для дали и близи.

9. Определение запаса относительной аккомодации с помощью приставления отрицательных линз в пробную оправу с коррекцией для дали при чтении пациентом текста № 4 таблицы Сивцева.

10. Определение величины отношения АК/А по методике В. И. Поспелова и О. В. Петрушко [21]. Отношение АК/А определяется при полной коррекции, обеспечивающей максимальную остроту зрения. Подобранные корригирующие линзы устанавливаются в пробной оправе в точном соответствии с величиной межзрачкового расстояния, измеренного при зрении вдаль. Этот показатель соответствует размеру В и используется при расчете аккомодативной конвергенции. Перед одним глазом обследуемого устанавливается цилиндр Maddox, величина фории измеряется с помощью офтальмокомпенсатора. Величины АK и АK/А рассчитываются по следующим уравнениям: $\mathrm{A}=100 / \mathrm{P}_{\sigma}-100 / \mathrm{P}_{д} ; \mathrm{AK}=\mathrm{A}$ $\mathbf{x} \mathbf{B}-\mathbf{F}_{д}+\mathbf{F}_{\tilde{6}}$, где $\mathrm{AK}$ - величина затрат аккомодативной конвергенции, пр. дптр (призменные диоптрии); $P_{\tilde{6}}, P_{д}-$ расстояние от базиса до ближней и дальней точек, в которых находится источник света и производится измерение фории,

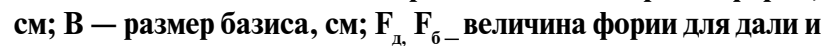
для близи, пр. дптр (величина экзофории вводится в формулу со знаком «-», а эзофории - со знаком «+»).

11. Осмотр глазного дна с широким зрачком бинокулярным налобным офтальмоскопом для определения стадий морфологических изменений глазного дна.

12. Исследование при биомикроскопии: форма мениска на оптическом срезе; равномерность мениска на протяжении края века и наличие «черной линии»; наличие конъюнктивальных складок параллельных лимбу (КСПЛ); эпителиопатия контактирующей конъюнктивы века; наличие включений в слезную пленку; нарушение тока слезы; время разрыва слезной пленки (ВРСП) без линзы; ВРСП с МКЛ; характер и частота морганий; толщина липидного слоя в слезной пленке; оценка эпителиальных изменений бульбарной конъюнктивы и роговицы с помощью витальных красителей $(0,1$ \% флюоресцеинат натрия, 1 \% лисаминовый зеленый, высокомолекулярный флюоресцеин) у лиц, носящих МКЛ и очки в контрольной группе; оценка степени неоваскуляризации роговицы у лиц, носящих МКЛ и очки в контрольной группе; оценка состояния стекловидного тела; фотодокументация имеющихся изменений бульбарной конъюнктивы и роговицы у лиц, носящих контактные линзы в течение 5-10 летнего срока.

13. Кератотопография.

14. А-сканирование

Критериями отбора детей в группу для назначения мягких контактных линз и ОК-линз была прогрессирующая близорукость, ортофория, экзофория до $5 \Delta$ (призменных диоптрий, пр. дптр.), эзофория до $2 \Delta$, снижение запаса относительной аккомодации, нежелание носить очки.
При выборе «очки или МКЛ» врачами и родителями часто не учитывается еще один важный аспект: защита глаз от ультрафиолетового излучения (УФИ) при использовании МКЛ обеспечивается в большей степени, чем очками. Детям труднее подобрать светозащитные очки, дети их плохо носят, так как они ограничивают их подвижность. УФИ обладает кумулятивным накоплением в организме: 80 \% накопленного УФИ за жизнь приходится на детский возраст. Хрусталик ребенка пропускает 80 \% ультрафиолетовых лучей, хрусталик 30-летнего человека пропускает только $10 \%$ УФИ. Поэтому уровень защиты сетчатки, макулы от губительного воздействия УФИ у детей при ношении МКЛ существенно выше, что является значительным преимуществом МКЛ.

РЕЗУЛЬТАТЫ. Сравнение показателей параметров близорукости в группах сравнения, носящих МКЛ и очки, представлено в табл. 1.

Как видно из табл. 1, прогрессирование близорукости существенно замедлилось в группе пациентов, где основным средством коррекции были мягкие контактные линзы с полной коррекцией, причём близорукость стабилизировалась устойчиво в той подгруппе, где первым средством коррекции аметропии были МКЛ. Среднее увеличение длины передне-задней оси глаза также существенно замедлилось в группах пациентов, носящих МКЛ с полной коррекцией. Также в результате ношения МКЛ восстановился запас аккомодации и стал соответствовать возрастной норме, а трофические изменения на глазном дне, связанные со стадиями близорукости, были выражены в меньшей степени у пациентов, носящих мягкие контактные линзы, в сравнении с пациентами, носящими очки. Ограничения жизнедеятельности, связанные с наличием близорукости, выражены в меньшей степени в группе детей и подростков, выбравших средством коррекции мягкие контактные линзы.

При наблюдении за пациентами-детьми на протяжении 5-10 лет при соблюдении ими правил ношения, ухода, сроков замены МКЛ нами были выявлены следующие умеренно выраженные признаки офтальмопатии: гиперемия лимба; прокрашивание бульбарной конъюнктивы и роговицы красителями (бывает и в норме); неоваскуляризация (готовность роговицы к патологическим изменениям); большинство пациентов имеет неоваскуляризацию слабой степени, меньшинство среднюю степень, высокой степени у детей и подростков не встречалось. Вероятно, это связано с тем, что детям изначально рекомендовалось носить линзы плановой замены, а в настоящее время осуществлен их перевод на силикон-гидрогелевые линзы. Следует отметить, что с появлением силикон-гидрогелевых линз опасность негативного воздействия на роговицу, на зону стволовых клеток в лимбе, значительно снизилась. На это указывает тот факт, что в гидрогелевых линзах эпителий утончается на $20 \%$, в силикон-гидрогелевых - на $6 \%$ [45]. 
Показатели параметров близорукости в группах, носящих МКЛ и очки

\begin{tabular}{|c|c|c|c|c|c|c|c|c|}
\hline \multirow{4}{*}{ Параметры глаз } & \multicolumn{6}{|c|}{ Приобретённая миопия (срок ношения 7 -12 лет) } & \multirow{2}{*}{\multicolumn{2}{|c|}{$\begin{array}{c}\text { Миопический } \\
\text { астигматизм }\end{array}$}} \\
\hline & \multicolumn{2}{|c|}{ слабой степени } & \multicolumn{2}{|c|}{ средней степени } & \multicolumn{2}{|c|}{ высокой степени } & & \\
\hline & в МКЛ & в очках & в МКЛ & в очках & в МКЛ & в очках & в МКЛ & в очках \\
\hline & \multicolumn{8}{|c|}{$\mathbf{M} \pm \sigma$} \\
\hline $\begin{array}{l}\text { Прибавка } \\
\text { прогресси- } \\
\text { рования } \\
\text { близоруко- } \\
\text { сти, Д }\end{array}$ & $0,61 \pm 0,28$ & $0,97 \pm 0,18$ & $1,12 \pm 0,48$ & $1,38 \pm 0,42$ & $1,25 \pm 0,45$ & $1,64 \pm 0,31$ & $0,85 \pm 0,25$ & $1,08 \pm 0,75$ \\
\hline $\begin{array}{l}\text { Острота зре- } \\
\text { ния, Д }\end{array}$ & 1,0 & $0,83 \pm 0,15$ & $0,94 \pm 0,6$ & $0,72 \pm 0,16$ & $0,88 \pm 0,12$ & $0,64 \pm 0,21$ & $0,82 \pm 0,14$ & $0,67 \pm 0,51$ \\
\hline $\begin{array}{l}\text { Экзофория, } \\
\text { прдптр }\end{array}$ & $2,25 \pm 0,25$ & $2,37 \pm 0,21$ & $3,0 \pm 1,0$ & $3,76 \pm 0,31$ & & & & \\
\hline АK/А вблизи & $3,8 \pm 1,23$ & $3,41 \pm 1,12$ & $4,38 \pm 1,45$ & $6,58 \pm 1,41$ & $5,46 \pm 1,74$ & $8,25 \pm 1,35$ & $5,66 \pm 1,44$ & $7,35 \pm 1,01$ \\
\hline $\begin{array}{l}\text { Запас от- } \\
\text { носительной } \\
\text { аккомода- } \\
\text { ции, Д }\end{array}$ & $4,57 \pm 0,65$ & $3,88 \pm 0,41$ & $4,2 \pm 0,63$ & $3,81 \pm 0,54$ & $3,74 \pm 0,82$ & $1,82 \pm 0,97$ & $2,91 \pm 0,96$ & $1,25 \pm 0,51$ \\
\hline $\begin{array}{l}\text { Длина перед- } \\
\text { незадней оси } \\
\text { глаза, мм }\end{array}$ & $\begin{array}{c}24,62 \pm \\
0,71\end{array}$ & $\begin{array}{c}24,58 \pm \\
0,82\end{array}$ & $25,8 \pm 0,31$ & $\begin{array}{c}25,92 \pm \\
0,29\end{array}$ & $\begin{array}{c}27,56 \pm \\
0,74\end{array}$ & $\begin{array}{c}27,98 \pm \\
0,81\end{array}$ & $26,1 \pm 0,99$ & $26,9 \pm 0,93$ \\
\hline $\begin{array}{l}\text { Глазное дно: } \\
\text { ДЗН, } \\
\text { макулярная } \\
\text { область, } \\
\text { периферия } \\
\text { сетчатки }\end{array}$ & $\begin{array}{c}\text { Миопиче- } \\
\text { ский конус } \\
\text { менее 1/4 } \\
\text { диаметра } \\
\text { диска }\end{array}$ & $\begin{array}{c}\text { Миопиче- } \\
\text { ский конус } \\
\text { менее 1/4 } \\
\text { диаметра } \\
\text { диска }\end{array}$ & $\begin{array}{c}\text { Миопиче- } \\
\text { ский } \\
\text { конус до } \\
1 / 2 \\
\text { диаметра } \\
\text { диска }\end{array}$ & $\begin{array}{c}\text { Миопиче- } \\
\text { ский } \\
\text { конус до } \\
1 / 2 \\
\text { диаметра } \\
\text { диска, дис- } \\
\text { пигмента- } \\
\text { ция вма- } \\
\text { кулярной } \\
\text { области }\end{array}$ & $\begin{array}{c}\text { Миопиче- } \\
\text { ский } \\
\text { конус до } \\
1 / 2 \\
\text { диаметра } \\
\text { диска, дис- } \\
\text { пигмента- } \\
\text { ция вма- } \\
\text { кулярной } \\
\text { области }\end{array}$ & $\begin{array}{c}\text { Миопиче- } \\
\text { ская } \\
\text { стафило- } \\
\text { ма, } \\
\text { диспиг- } \\
\text { ментация } \\
\text { в макуляр- } \\
\text { ной } \\
\text { области, } \\
\text { ПХРД }\end{array}$ & $\begin{array}{c}\text { Миопиче- } \\
\text { ский } \\
\text { конус до } \\
1 / 2 \\
\text { диаметра } \\
\text { диска, дис- } \\
\text { пигмента- } \\
\text { ция вма- } \\
\text { кулярной } \\
\text { области }\end{array}$ & $\begin{array}{c}\text { Миопиче- } \\
\text { ский } \\
\text { конус до } \\
1 / 2 \\
\text { диаметра } \\
\text { диска, дис- } \\
\text { пипиента- } \\
\text { ция } \\
\text { вмакуляр- } \\
\text { ной } \\
\text { области }\end{array}$ \\
\hline
\end{tabular}

Несомненно, польза от использования детьми МКЛ в сравнении с очками значительно превышает их негативные стороны. Изменения на глазном дне, связанные со степенью близорукости у детей, пользующихся МКЛ, выражены в меньшей степени, менее патологичны, чем у сверстников с той же степенью близорукости, пользующихся очками с недокоррекцией. Можно предположить, что полная адекватная коррекция близорукости контактными линзами оказывает положительное влияние на структуру и обменные процессы, происходящие в заднем полюсе глаза. Неполная коррекция миопии и астигматизма очковыми линзами ведёт к относительно большим нарушениям аккомодации и конвергенции, нарушению работы цилиарной мышцы, появлению более выраженных деформаций склеры, а также проявлений осложненной близорукости на глазном дне, в сравнении с более адекватной коррекцией контактными линзами тех же степеней близорукости.

ОК-линзы оказались еще более эффективным средством торможения близорукости, вероятно за счет слабой гиперкоррекции в первой половине рабочего дня.
По предварительным данным наших исследований замена ОК-линз с усилением отмечалась в 5 \% случаев: за 3 года наблюдений из 45 человек , носящих ОК-линзы, у одного усиление рефракции составило 0,5 Д, а у трёх - 0,25 Д, при этом у всех остальных наблюдаемых миопия практически не прогрессировала. Эти наши результаты коррелируют с данными других исследований. В частности, по данным Е. П. Тарутты и Т. Ю. Вержанской, за 2 года наблюдений заметного роста аксиальной длины глаза и усиления рефракции обнаружено не было [31]. Зарубежные исследования также подтверждают эту тенденцию: скорость прогрессирования близорукости до подбора ОК-линз составляла в среднем 0,37 Д в год, при подборе и ношении ОКлинз скорость прогрессирования близорукости составила 0,03 Д в год [38]. Учитывая эти положительные практические результаты, следует отметить, что ортокератология может стать одним из методов первого выбора при коррекции прогрессирования миопии у детей.

В целом анализ полученных данных показал, что ранняя полная адекватная коррекция миопии мягкими контактными линзами или ОК-линзами 
обеспечивает у здоровых детей и подростков следующие достоверные положительные сдвиги по сравнению с детьми, носящими очки:

- существенное замедление прогрессирования близорукости за счет восстановления увеосклерального оттока при реализации фаз аккомодации, отличающихся от крайних (взгляд полностью вдаль и полностью вблизь); устранения периферического дефокуса; нормализации метаболических процессов в заднем отрезке глаза.

• уменьшение числа осложнений, связанных с прогрессирующей близорукостью;

- повышенную адаптацию в окружающей среде без ограничения вида жизнедеятельности, связанного с близорукостью, снятия ограничений в занятиях активными видами деятельности, спортом, выборе досуга, а в последующем - и профессии.

По сути, полученные нами клинические данные подтверждают метаболическую теорию миопии. При достижении максимальной остроты зрения в контактных линзах с полной коррекцией, пациент становится эмметропом или гиперметропом слабой степени (+ 0,5 D). Функциональное состояние зрительного аппарата миопа, откорригированного с помощью МКЛ или ОК-линзами, можно приравнять к функциональному состоянию эмметропа. Только в МКЛ достигается полная коррекция аметропии, отсутствуют аберрации, связанные с ношением очковых линз, отсутствует уменьшение изображения предметов, совпадают оптический и зрительный центры. При достижении максимальной остроты зрения мягкими контактными линзами восстанавливается работа цилиарной мышцы, нормализуется аккомодация, конвергенция, восстанавливается трофика. Функциональное состояние органа зрения близорукого человека становится тождественным состоянию здорового человека, то есть эмметропа.

\section{ВЫВОдЫ}

1. Ранняя полная адекватная коррекция приобретённой миопии контактными линзами у детей и подростков обеспечивает выраженное замедление её прогрессирования или полную стабилизацию за счёт небольшого сдвига фокуса за сетчатку для нормализации метаболических процессов в заднем полюсе глаза.

2. Эффект от использования мягких контактных линз (МКЛ) и ортокератологических линз (ОК-линзы) как средства коррекции зрения, способствуюшего замедлению прогрессирования близорукости, связан с расположением фокуса за сетчаткой, что во время зрительной нагрузки позволяет избежать развития миопии по нагрузочному или разгрузочному типу.
3. Полученные на практике клинические данные подтверждают физиологическую обоснованность основных положений метаболической теории миопии.

\section{СПИСОК ЛИТЕРАТУРЫ}

1. Абрамов М. В. Непрерывный режим ношения - преимущества и риски // Вестн. оптометрии. - 2009. № 6. - С.29-32.

2. Аветисов Э. С. Близорукость. - М., Медицина, 1986. $-233 \mathrm{c}$.

3. Березина Т. Г. Неврологические аспекты проблемы близорукости у детей. - Перинатальная неврология. - Казань, 1983. - С.140-142.

4. Галкин Н. Н. Пособие по подбору очков. Под ред. В. В. Волкова. - Л., Медгиз, 1960. - 184 с.

5. Гусева М. Г. Ранняя стабилизация миопии с помощью рациональной коррекции. - В сб. тр. научно - практич. конф. офтальмол. «Филатовские чтения», посв. 75-летию основ. ГУ «Институт глазных болезней и тканевой терапии им. В. П. Филатова НАМН Украины, 2011. - С.262-264.

6. Гусева М. Г. Стабилизация миопии у детей при применении контактных линз. Гл. 11. - В кн.: Офтальмоконтактология / Под.ред. А. Б. Беливитина. - СПб.: ВМедА, 2010. - С. 231-247.

7. Дашевский А. И. Близорукость. - М.: Медицина, 1962. -145 c.

8. Дашевский А. И. Ложная близорукость. - М.: Медицина, 1973. - $148 \mathrm{c}$.

9. Добровольский В. И. О различных изменениях астигматизма под влиянием аккомодации. - Военно-медицин. журн. - 1868. - Т.103. - 9. - 3. - С. 34-54.

10. Затулина Н. И. Изменения параметров склеры в реализации сил внутриглазного давления. - В сб.: Физиология и патология внутриглазного давления. Республиканский сборник научных трудов., М., 1987. - C.38-42.

11. Зиновьева Н. В., Светлова О. В., Яндиев Я. И., Яфаи Ю. Р. Использование взаимосвязи биомеханизмов аккомодации и оттока для профилактики глазных патологий // VIII Всероссийский съезд по теоретической и прикладной механике. - Пермь, 2001. - C.278.

12. Иванов А. А. Рефракция глаз у детей в первые месяцы жизни. - Дисс. С. - Петербург, 1898.

13. Кошиц И. Н., Светлова О. В. Онтогенез формирования необходимой длины глаза и метаболическая теория патогенеза миопии. - В сб.: Биомеханика глаза 2007 / МНИИ ГБ им. Гельмгольца, 2007. С.13-33.

14. Кошиц И. Н., Светлова О. В. Взимодействие путей оттока водянистой влаги с механизмом аккомодации. Учебное пособие. - СПб.МАПО. - 2002. - 31 с.

15. Кошиц И. Н., Светлова О. В. Онтогенез формирования необходимой длины глаза в детстве и метаболическая теория патогенеза миопии // Глаз. - 2007. - № 6 (58). - С.16-31.

16. Кошиц И. Н., Светлова О. В., Макаров Ф. Н. Метаболическая теория прогрессирующей миопии. - Мат. лы 12 съезда офтальмол. Украины. - Одесса, 2010. C. 257 . 
17. Кошиц И. Н., Светлова О. В., Макаров Ф. Н. Приобретённая миопия как классический случай преобладания аккомодации над оттоком // «Бинокулярные и глазодвигательные нарушения»: Сб. стат. научно- практ. конф. МНИИ ГБ им. Гельмгольца. - М., 2007. - C.135-137.

18. Кузнецова М. В. Причины развития близорукости и ее лечение. - М.: Медицина, 2004. - 168 с.

19. Махова М. В., Парфенова Н. П. Использование мягких торических контактных линз для коррекции астигматизма у детей // Вестн. оптометр. - 2009. № 5. - C. 37-43.

20. Петухов В. М., Медведев А. В. Особенности возникновения и прогрессирования школьной близорукости в условиях современного учебного процесса и ее профилактика: учеб.. - метод. пособие. - Самарский ГМУ, Ин-т последиплом. образования. - Самара, 2004. $-23 \mathrm{c}$.

21. Поспелов В. И., Петрушко О. В. Новые технологии в диагностике и лечении заболеваний глаз. - Красноярск, 1996. - С.31-34.

22. Проскурина О. В. Развитие рефракции в детском возрасте // Вестн. офтальмолог. - 2003. - № 6. - С.5157.

23. Рожкова Г. И., Матвеев С. Г. Зрение детей. Проблемы оценки и функциональной коррекции. - М Наука, 2007. - C. 54-66.

24. Розенблюм Ю. 3. Рефракция, аккомодация и зрение // В сб. научн. Трудов «Клиническая физиология зрения». - изд. АО «Русомед», М., 1993. - С.180-198.

25. Светлова О. В. Биомеханические особенности взаимодействия основных путей оттока внутриглазной жидкости в норме и при открытоугольной глаукоме // Биомеханика глаза / МНИИ ГБ им. Гельмгольца. М., 2001. - C.95-107.

26. Светлова О. В. Функциональные особенности взаимодействия склеры, аккомодационной и дренажной систем глаза при глаукомной и миопической патологии. - Автореф. дисс...Д.м.н. - М., 2010. - 53 с.

27. Светлова О. В., Кошиц И. Н., Куглеев А. А. Физиологические особенности работы ресничной мышцы при направленных рефракционных вмешательствах // Тез.докл. VII Съезда офтальмологов России. - ч.1. M., 2000. - C.287.

28. Светлова О. В., Кошиц И. Н. Современные биомеханические представления о теории аккомодации Гельмгольца // В кн.: Биомеханика глаза 2001. - М., МНИИ ГБ им. Гельмгольца. - 2001. - С. 142-160.

29. Светлова О. В., Крылова И. С., Зиновьева Н. В., Кошиц И. Н. Биомеханические аспекты возможных общих причин наследственной и приобретённой миопии. - Близорукость, нарушения рефракции, аккомодации и глазодвигательного аппарата: Сб.тр. межд. симп. МНИИ ГБ им. Гельмгольца. - М., 2001. C.234-236.

30. Сердюченко В. И., Вязовский И. А. Исследование аккомодации в различных меридианах глаза и моди- фицированная методика лечения её нарушений при гиперметропической амблиопии // В сб.: Биомеханика глаза 2004. - МНИИ ГБ им. Гельмгольца, М . 2004. - C.33-37.

31. Тарутта Е. П., Вержанская Т. Ю. Возможные механизмы тормозящего влияния ортокератологических линз на прогрессирование миопии // Российск. офтальмологич. журн. - 2008. - № 2. - С.26-30.

32. Тейлор Д., Хойт К. Детская офтальмология. - Пер. с англ. - М.; СПб.; ЗАО «Издательство БИНОМ», «Невский диалект», 2002. - 248 с.

33. Трон Е. Ж. Изменчивость элементов оптического аппарата глаза и её значение для клиники. - Л. 1947.

34. Фаллух Ш. Ш., Розенблюм Ю. З. Статическая и динамическая рефракция глаза в зоне дальнейшего видения при различных методах исследования // В сб. «Динамическая рефракция глаза в норме и при патологии». - М., 1981. - - С.87-89.

35. Хаитова К. Н. Влияние общих заболеваний организма на аккомодационную способность глаз у детей. Миопия. - М., 1974. - С.24-27.

36. Хохлова Т. В., Панова И. Г. Становление аккомодации у молодых болотных черепах emys orbicularis $\mathrm{L} / / \mathrm{CeH}-$ сорные системы. - 2006. - 20. - 4. - С. 300-308.

37. Шамшинова А. М., Волков В. В. Функциональные методы исследования в офтальмологии. - М., Медицина. $-416 \mathrm{c}$.

38. Alharbi A., Swarbrick H. A. The effects of overnight orthokeratology lens wear on corneal thickness // Invest Ophthalmol. Vis. Sci. - 2003. - 44. - P.2518. - .2523.

39. Chung K., Mohidin N., OrLeary D. J. Undercorrection of Myopia Enhances rather than Inhibits Myopia Progression // Vis Research. - 2002. - Vol.42. - P.2555-2559.

40. Day M., Strang N. C., Seidel D., Gray L. S., Mallen E. A. Refractive group differences in accommodation micro fluctuations wise changing accommodation stimulus // Ophtalmic Physiol Opt. - 2006. - Vol.1. - P.88-96.

41. Edwards M. H. The development of myopia in Hong Kong Children between the ages of 7 and 12 years a five- years longitudinal study // Ophthal. Physiol. Opt. - 1999. Vol.19. - P.286-294.

42. Giga R. Myopia Part 2 // Environment Optician. 2004. - Vol.237. — № 5956. - P. 37-39

43. Grosvenor T. Primary Care Optometry. Fifth Edition. 2007. - P.75-94, 510.

44. Goss D. A., Wickham M. G. Retinal-image mediated Ocular Growth as a Mechanism for Juvenile Onset Myopia and for Emmetropization. A Literature review // Doc. Ophthalmol. - 1995. - Vol.90. — № 4. - P.341-375.

45. Holden B. A., Sweeney D. F., Vannas A., Nilsson K., Efron N. Effects of Long - term extendet contact lens wear on the human cornea // Invest Ophthalmol. Vis. Sci. - 1985. - 26. - P.1489-1501.

46. Lin LLK HA, Hsiao CK, Chen CJ. Prevalence of Myopia in Taiwanese School-children: 1983 to 2000. - Ann Acad Med Singapore. - 2004. - Vol. 33. - P.27-33. 


\title{
STABILIZATION OF THE ACQUIRED MYOPIA IN CHILDREN WITH THE AID OF CONTACT LENSES
} FROM THE STANDPOINT OF THE METABOLIC THEORY OF MYOPIA

\author{
M. G. Guseva, O. V. Svetlova, I. N. Koshits \\ St.Petersburg, Russia
}

The results of personal research have shown that using the full correction for distance leads to substantial deceleration of acquired myopia in the group of healthy children and adolescents aged 5 to 14 years where the primary means of correction were soft contact lenses or orthokeratological lenses. Shifting the focus behind the retina due to low overcorrection in the soft contact lens was monitored using duochrome test. Myopia stabilized $(p=0.01)$ in the group where patient's both eyes were corrected completely and full and the method of correction was only soft contact lenses. Also as a result of rational correction of myopia and astigmatism accommodation stock increased and became matching the age norm as well as the AC/A ratio. Trophic changes in the ocular fundus associated with stages of myopia were less clearly marked for patients wearing soft contact lenses, compared with patients wearing glasses. Orthokeratological lenses were even more effective in inhibition of myopia $(p=0.05)$, probably due to the low overcorrection in the first half, leading to normalization of metabolism of the back of the sclera. Furthermore young people wearing contact lenses face less restriction in lifestyle, education, hobbies, social and psychological adaptation in comparison with their spectacles wearing peers. Metabolic theory of myopia has been able to explain the clinical results obtained.

УДК 617.753.4:617.726-073.581

\section{ФУНКЦИОНАЛЬНОЕ СОСТОЯНИЕ АККОМОДАЦИОННОГО АППАРАТА У ПАЦИЕНТОВ С ПРЕСБИОПИЕЙ}

\author{
П. А. Бездетко, д-р мед. наук, проф., М. А. Щадных, аспирант
}

Харьковский национальный медицинский университет

\begin{abstract}
При обстеженні 150 пацієнтів (275 очей) пресбіопічного та предпресбіопічного віку з еметропією, гіперметропією та міопією слабкого ступеня встановлено достовірне зниження амплітуди акомодації порівняно з контролем до 1,96 дптр при еметропії, 1,41 дптр при сіперметропії та 3,39 дптр при міопії. Резерви акомодації також зменшувались з віком до 0,05 дптр при еметропії, до 0,03 дптр при гіперметропії та не змінювались при міопії, складаючи в середньому 0,69 дптр. Віддалення області відносного спокою акомодації було при усіх видах рефракції, але найбільш інтенсивно цей процес відбувався у пацієнтів з гіперметропічною рефракцією. Отримані дані більшою мірою корелювали з величиною рефракції, ніж з віком пацієнтів. Таким чином, при пресбіопії страждають всі компоненти акомодації, а значущими факторами у діагностиці та корекції повинні бути стан акомодації та показник рефракції.
\end{abstract}

Ключевые слова: пресбиопия, амплитуда аккомодации, область относительного покоя аккомодации, аккомодационно-дезаккомодационные резервы.

Ключові слова: пресбіопія, амплітуда акомодації, область відносного спокою акомодації, акомодаційно-дезакомодаційні резерви.

Введение. Пресбиопия - это возрастное снижение зрения, которое является результатом постепенной утраты аккомодации с возрастом и последующего множественного воздействия на качество жизни и зрения [5]. В связи с сокращением амплитуды аккомодации, область ясного зрения становится неприемлемой для выполнения пациентом повседневных задач. В результате, те лица, которые более часто заняты напряженной зрительной работой вблизи, подвержены возникновению наибольших сложностей. Учитывая важность для любого развитого общества чтения и работы на близких и средних дистанциях, пресбиопия имеет не только клиническое, но и социальное значение.

Было установлено, что в Западно-Азиатском регионе, к которому относится Украина, манифестация пресбиопии наступает в 45 лет, распространенность среди населения старше этого возраста составляет $83 \%$, что в абсолютном количестве в 2010 году соответствовало 35,5 млн., а в 2020 и 2050 предположительно будет равно 42,3 млн. и 50,3 млн. [3]. Не вызывая снижения трудоспособности и будучи

(C) П. А. Бездетко, М. А. Щадных, 2011 